\title{
MAŁGORZATA BOREK
}

Uniwersytet Śląski

Katowice, Polska

\section{Zdania wyrażające zdolności i talent $\mathrm{w}$ języku polskim i rosyjskim}

Z punktu widzenia psychologii zdolności to inaczej instrumentalne wyznaczniki sprawności człowieka ${ }^{1}$. Ludzie różnią się między sobą w poszczególnych zakresach swej aktywności zarówno pod względem efektywności, jak i szybkości i energii, którą są w stanie włożyć w działanie. Wymienione cechy działania mogą wzajemnie na siebie wpływać, gdyż przy niektórych rodzajach czynności szybkość może decydować o efektywności, z kolei sprawność, z jaką człowiek potrafi wykonywać daną czynność, może rzutować na jej tempo lub wielkość wysiłku energetycznego. Ostatecznie mamy do czynienia z wyodrębnieniem dwóch rodzajów wyznaczników działania: „tych, które warunkują jego sprawność, i tych, które są podstawowymi determinantami jego właściwości formalnych. Pierwsze nazywa się zdolnościami, drugimi są cechy temperamentu"2.

Sprawność działania jest zależna zarówno od czynników zewnętrznych, jak i wewnętrznych, czyli od motywacji, aktualnego stanu psychicznego i stopnia wprawy, z jaką jednostka wykonuje określony rodzaj czynności. „Wszystkie te czynniki stanowią jednak tylko warunki ujawniania się przez jednostkę możliwości"3. Ludzie mogą wykorzystywać te możliwości lub nie, czyli w różnym stopniu posługują się posiadanymi zdolnościami w konkretnych sytuacjach.

W Stowniku psychologii autorstwa Arthura i Emily Reber zdolność zostaje zdefiniowana jako „kompetencja, biegłość, sprawność, zręczność czy talent, dzięki którym ktoś może dokonać określonego czynu w danym czasie, bez jakiegokolwiek dodatkowego treningu"4. Według autorów kluczowe znaczenie ma odróżnienie tego terminu od pojęcia „uzdolnienie”, które związane jest z możliwoś-

\footnotetext{
${ }^{1}$ Z. Włodarski, A. Matczak, Wprowadzenie do psychologii, Warszawa 1987, s. 327.

2 Ibidem, s. 326.

${ }^{3}$ Ibidem, s. 327.

${ }^{4}$ A. Reber, E. Reber, Stownik psychologii, red. I. Kurcz, K. Skarżyńska, Warszawa 2005, s. 923.
} 
ciami potencjalnymi, czyli takimi, jakie dana osoba osiągnie dzięki wyuczeniu się. Innymi słowy, uzdolnienie to „potencjał do nabywania umiejętności; [...] zakłada się, że poziom wykonania będzie rósł znacząco wraz z dodatkowym treningiem"s.

Okazuje się, że rozróżnienie tych dwóch terminów nie znajduje odzwierciedlenia w słownikach języka polskiego i rosyjskiego. W Słowniku współczesnego języka polskiego termin ,zdolność” posiada następujące znaczenia:

1. Wrodzona predyspozycja do opanowywania jakichś umiejętności, łatwość uczenia się, talent (np. wybitne, duże, mierne zdolności; zdolności muzyczne, matematyczne); 2. Sprawność, możność wykonania czegoś; zdatność do robienia czegoś (np. zdolność myślenia, zdolność owocowania) ${ }^{6}$.

Jak widać, pierwsze znaczenie odpowiada psychologicznemu terminowi ,uzdolnienie" i odnosi się do człowieka, natomiast drugie tyczy się pojęcia „,zdolność" i niekoniecznie związane jest z działalnością człowieka. Definicja ta pokrywa się z objaśnieniem rosyjskiego terminu способность, który możemy znaleźć w Словаре русского языка Сергейа Ожегова:

1. Природная одаренность, талантливость (человек с большими способностями, умственные способности, способности к музыке); 2. Умение, а также возможность производить какие-нибудь действия (способность двигаться, покупательная способность населения, пропускная способность железнодорожных дорог) ${ }^{7}$.

Przytoczone definicje świadczą o tym, że przy opisywaniu uzdolnień w języku polskim i rosyjskim leksemy zdolność/cnособность są używane z reguły w formie liczby mnogiej: „Mówiła, że ma detektywistyczne zdolności” (A. Bahdaj, Wakacje $z$ duchami); „Mają one na celu ustalenie zainteresowań i zdolności dzieci” („Głos Pasłęka” 2004); „Молодые специалисты, проявившие способности к научной деятельности, могут поступать в аспирантуру” („Поиск” 12.09.2003); „А музыкальные способности у нее точно от меня” („Домовой” 4.04.2002).

Jednak leksemy zdolności/cnособности w liczbie mnogiej nie są zarezerwowane wyłącznie dla określania zdolności ludzkich, o czym świadczą przykłady: „Rozważamy gospodarkę w warunkach niepełnego wykorzystania zdolności wytwórczych” (R. Milewski, Podstawy ekonomii); „Для обработки нарастающего потока информации нужны другие способности машины: например, способность мыслить подобно человеку” (Е. Велтистов, Победитель невозможного).

W niniejszej pracy postaramy się opisać izosemiczne i nieizosemiczne modele składniowe, bazując na teorii Galiny Zołotowej. Zdaniem badaczki w konstrukcjach izosemicznych „, сохраняется соответствие между категориальными значениями структурных компонентов предложения и категориальными

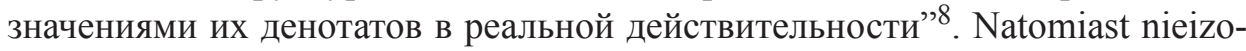

${ }^{5}$ Ibidem, s. 845 .

${ }^{6}$ Stownik wspótczesnego języka polskiego, red. B. Dunaj, Warszawa 1996, s. 1351.

${ }^{7}$ С.Н. Ожегов, Словарь русского языка, под ред. Н.Ю. Шведовой, Москва 1990, s. $755-756$.

${ }^{8}$ Г.А. Золотова, Коммуникативные аспекты русского синтаксиса, Москва 2001, s. 127. 
semiczne modele zdaniowe polegają na naruszeniu tej równowagi, pojawieniem się, zgodnie z prawem kompensacji gramatycznej, dodatkowych, niejako zbędnych środków językowych ${ }^{9}$. W ten sposób, zdaniem G.A. Zołotowej, izosemiczne modele typu „Спортсмен прыгает”; „Он ловок” pozostają w opozycji do modeli nieizosemicznych „Спортсмен делает прыжок”; „Он отличаетчя ловкостью”.

Przykłady do analizy zostały zaczerpnięte z korpusów języka polskiego i rosyjskiego oraz ze stron internetowych.

Za podstawowe, izosemiczne konstrukcje, wyrażające charakterystykę osoby uzdolnionej można uznać w języku polskim zdania z leksemem zdolny, którym w języku rosyjskim odpowiadają sformułowania z leksemem способный: „Маcie tam zdolnego chirurga Leśniowskiego" (J. Brzechwa, Gdy owoc dojrzewa); „Myśmy byli zdolni i dzisiejsi reżyserzy też są zdolni” („Polityka” 2.05.2005); „Сын - способный компьютерщик, живёт в Америке, под Сан-Франциско” (В. Токарева, Своя правда); „Он настолько способный, что может выучить любой язык, даже японский” (С. Спивакова, Не всё).

Przymiotniki zdolny/cnoсобный mogą występować w funkcji przydawki lub orzeczenia imiennego. Okazuje się, że mogą one wyrażać zarówno uzdolnienia, jak i modalność. Natomiast rosyjski przymiotnik w formie krótkiej способен występuje tylko w funkcji orzeczenia i posiada znaczenie modalne 'мочь, быть в состоянии что-то сделать’ : „Парни смотрели на меня, словно прикидывали, на что я способен" (В. Аксёнов, Звёздный билет).

Wśród różnych rodzajów zdolności na szczególną uwagę zasługują talent i genialność, które dotyczą wyłącznie działalności człowieka. Według Józefa Pietera talent oznacza

wybitne uzdolnienia specjalne do działań twórczych lub odtwórczych. W tym sensie mówi się np. o talencie malarskim, muzycznym, ale nie o inteligencji malarskiej, muzycznej itp. Odróżnia się również genialność od talentu. Genialność jest zdolnością — podobnie jak talent — specjalną, ale do twórczości wybitnie oryginalnej ${ }^{10}$.

Autorzy Słownika współczesnego języka polskiego definiują talent jako:

1. Szczególne, wybitne uzdolnienie w jakimś kierunku, predyspozycje, zdolności; 2. Osoba wybijająca się w jakiejś dziedzinie, mająca naturalne predyspozycje do wykonywania określonych działalności, człowiek utalentowany (np. Pojawiły się młode talenty) $)^{11}$.

$\mathrm{Z}$ kolei талант to według Словаря русского языка:

1. Выдющиеся врождённые качества, особые природные способности (например, талант актёра, музыкальный талант); 2. Человек, обладающий такими качествами, способностями (например, молодые таланты) ${ }^{12}$.

W definicjach tych podkreśla się, że talent to zdolności wrodzone, naturalne.

\footnotetext{
${ }^{9}$ Ibidem.

10 J. Pieter, Stownik psychologiczny, Katowice 2004, s. 309.

11 Stownik współczesnego języka polskiego, s. 1120.

12 C.Н. Ожегов, op. cit., s. 786.
} 
Podobnie jak w przypadku zdolności, za izosemiczne modele składniowe przy opisie talentu można uznać zdania z przymiotnikami utalentowany/mалантливый: „Mateusz miał skoczyć tak, jak potrafi. Jest przecież bardzo utalentowany” (,Fakt” 2.09.2004); „To nie tylko piękna, ale i nieprawdopodobnie utalentowana aktorka” („Cosmopolitan” 2000, nr 8); „Zapisywał, dawał szanse, najbardziej utalentowani zostawali na stałe” („Tygodnik Podhalański” 1999, nr 24); „Да и режиссёр он талантливый, поэтому его картину можно считать событием” („Известия” 13.06.2002); „Сейчас будет выступать очень талантливый музыкант” (А. Алексин, Мой брат играет на кларнете).

W cytowanych przykładach przymiotniki utalentowany/mалантливый wуstępują w funkcji orzeczenia imiennego i przydawki przymiotnej, możliwe jest także użycie tych leksemów w funkcji substantywnej (np. „najbardziej utalentowani zostawali na stałe").

W języku rosyjskim istnieje również krótka forma przymiotnika талантлив, która pełni funkcję orzeczenia imiennego: „А талантлив был не только в музыке” (И. Грекова, Фазан); „Ей не пришлось долго входить в роль, она талантлива сама по себе” („Новгородские ведомости” 2012).

Talent jest tutaj przedstawiony jako cecha sprecyzowana przez swój stopień i dziedzinę (np. „не только в музыке; сама по себе”), czyli następuje uszczegółowienie informacji.

Dodatkowo dzięki możliwości przeciwstawienia pełnych i krótkich form przymiotnikowych w języku rosyjskim możliwe jest użycie swego rodzaju konstrukcji tautologicznych, które przypominają aforyzmy: „Вообще-то талантливый ребёнок тем и талантлив, что может запросто менять ипостаси: то он отпетый хулиган, а то вдруг — маленький светоч” („Вечерняя Москва” 16.05.2002); „Он был умён, талантлив - и известен как умный и т ал ан тл и в ый” („Новый Мир” 1990); „Физтехи как талантливые люди талантливы во всём” (,За науку” 2014).

Interesujące jest przeniesienie charakterystyki za pomocą przymiotników utalentowany/mалантливый z osób na zwierzęta, urządzenia i różne produkty: „Podobno to był bardzo utalentowany, piękny pies i wygrał wiele międzynarodowych wystaw” (W. Koch, Internetowa strona o psach); „Jedyna w swoim rodzaju i wielofunkcyjna elektryczna szczotka ROTOSOFT 4000: z uchwytu wybierane są funkcje: czyszczenie dywanów lub podłóg twardych — wszechstronnie utalentowana!” (Reklamy wyposażenia doти, 2000); „Это очень хороший, талантливый фильм, в котором играют великолепные актёры” („Вечерняя Москва” 16.05.2002); „Талантливые и страстные произведения любых жанров обычно выходят за пределы своей основной темы” („Октябрь” 2001).

Przykłady zdań rosyjskich świadczą o tym, że ocena produktów jest wynikiem stanowiska ich twórcy, na przykład reżysera i aktorów w przypadku filmu („талан- 
тливый фильм”) oraz pisarza w przypadku utworów („,талантливые произведения”). Mamy tutaj zatem do czynienia z metonimią „dzieło za twórcę”.

Słownik współczesnego języka polskiego jako synonim leksemu utalentowany podaje przymiotnik uzdolniony ${ }^{13}$. Przymiotnik ten może występować w funkcji orzeczenia imiennego lub przydawki przymiotnej: „Był zresztą niezwykle uzdolniony i zapowiadał się na wirtuoza" (J. Przybora, Przymknięte oko opaczności); „Wybitnie uzdolniony student mógłby się opłacać wydziałowi, gdyby ktoś płacił na jego kształcenie cztery do pięciu razy tyle, ile płaci ministerstwo” (,Gazeta Wyborcza" 26.09.1997).

W języku rosyjskim do charakterystyki osób uzdolnionych służą także przymiotniki даровитьй і одарённылй, odpowiednikiem których w języku polskim jest połączenie obdarzony talentem: „Он, конечно, музыкант и, если хотите знать, даровитый” (Л. Утесов, Спасибо, сердие!); „Познакомившись с Цукерманом поближе, я поняла, что музыкант он безусловно одарённый” (С. Спивакова, Не всё); „Był to autor obdarzony talentem literackim” (Z. Kosidowski, Opowieści bibilijne).

Leksem talent może występować w formie mianownika i w połączeniu z różnymi przymiotnikami posiadać znaczenie kwalifikacyjno-oceniające: „Mateusz jak przyszedł na pierwszy trening, to już umiał skakać. Naturalny talent" („Fakt” 1.05.2004); „В тридцать лет у него начисто отсутствует карьеризм. Он талант неизломанный, а гармоничный” (С. Спивакова, Hе всё); „К тому же Агаджанов в организационной сфере - выдающийся талант” (И. Кио, Иллюзии без иллюзий); ,- _..незаурядный талант, — продолжал Шишлин” (А. Азольский, Лопушок); „Рассказывают, что он- невероятный талант, лучшее перо современности" (И. Охлобыстин, Жизнь Вани Охлобыстина).

W powyższych konstrukcjach leksem talent oznacza osobę uzdolnioną. W połączeniu z przymiotnikiem (naturalny, неизломанный, гармоничный, вылающииися, незауряднылй, невероятный) występuje w funkcji orzeczenia imiennego z łącznikiem zerowym.

Osoba, która ma unikatowy, wrodzony talent, inaczej talent w czystej postaci, niezależący od wykształcenia, określana jest jako talent samorodny/caмородный таланm lub krótko jako samorodek/самородок: „Rugby i boks nie były obce Elliottowi, o którym naiwni mówią: samorodny talent, który trafia się raz na dziesiątki lat” („Sport dla Wszystkich” 1961, nr 12); „Nasz samorodek jest jeszcze do uratowania, ale nie przez trenera Apoloniusza Tajnera! Ten trener urósł, ponieważ przyczepił się do naszego wielkiego talentu” („Fakt” 2.06.2004); „Художник Майков составляет феноменальное явление в искусстве, как самородный талант, которому случайность открыла путь к искусству" (И. Гончаров, Н.А. Майков); „Он был очень одарен, Володя, самородок” (А. Рыбаков, Тяжельй песок).

13 Stownik współczesnego języka polskiego, s. 1194. 
W przytoczonych zdaniach zostaje podkreślone, że samorodny talent trafia się bardzo rzadko („raz na dziesiątki lat”), jest zjawiskiem fenomenalnym i objawia się często przypadkowo („случайность открывает ему путь”). W przykładzie opisującym samorodny talent Adama Małysza pojawiła się ciekawa metafora „ktoś urósł, gdyż przyczepił się do wielkiego talentu”, ukazująca zjawisko czerpania korzyści z czyjegoś talentu.

$\mathrm{Z}$ kolei osoba zupełnie pozbawiona talentu po polsku określana jest jako beztalencie, natomiast po rosyjsku jako бездарность: „- Tato... a ja... ja naprawdę jestem takie okropne beztalencie?” (K. Berwińska, Con amore); „ты полная бездарность, твоими стихами можно только подтираться, и то поцарапаешь задницу" (В. Катаев, Алмазный мой венеи).

Leksem talent może występować w przypadku zależnym i w połączeniu z przymiotnikiem pełnić funkcję kwalitatywu, czyli syntaktemu charakteryzującego, nazywającego cechę osoby lub przedmiotu ${ }^{14}$. Na przykład: „Kisling był człowiekiem dużego talentu i temperamentu” (J. Czapski, Patrzac); „Odszedł człowiek - lekarz, odszedł artysta o nieprzeciętnym talencie" (K. Mórawski, Kartki z dziejów Żydów warszawskich); „Мария Павловна считала своего мужа человеком большого таланта” (В. Гроссман, Все течёm); „На Пасхе вернулся из Москвы в Петербург один наш общий друг, человек большого таланта и большого легкомыслия" (В. Ходасевич, Гумилёв и Блок).

$\mathrm{W}$ języku polskim kwalitatyw wyrażony jest $\mathrm{w}$ formie dopełniacza („dużego talentu”) lub miejscownika z przyimkiem o („o nieprzeciętnym talencie”). W języku rosyjskim kwalitatyw posiada tylko formę dopełniacza bez przyimka („большого таланта”). Dodatkowo w języku rosyjskim pojawia się przydawka dopowiadająca, odnosząca się do rzeczownika $\partial p y z$.

Do charakterystyki i oceny czyjegoś talentu służą również zdania, których prymarnym przeznaczeniem jest wyrażenie znaczeń posesywnych. W języku polski jest to konstrukcja ktoś ma talent, natomiast w języku rosyjskim - y когото есть талант: „A mial jeszcze ponadto nietuzinkowy talent poetycki” (B. Gomulicka, Pisarze polskiego oświecenia); „Głos miał nieukładany, chropawy, tyle że ciepły, z leciutką nutą wschodniego zaśpiewu. Ale mi a 1 przyrodzony talent kontaktu z ludźmi, który nie każdemu nawet kaznodziei jest dany" („Tygodnik Powszechny” 1994, nr 43); „Obydwaj mają nieposkromiony talent do robienia show, sztuczek i żartów” (M. Cegielski, Masal); „Widziałem go, jak jeździł na nartach na Szymoszkowej, m a talent po Jaśku” („,Tygodnik Podhalański” 1999, nr 17); „Masz jakieś ukryte talenty?” („Cosmopolitan” 2000, nr 11); „У дочери же необычайный талант. Даже специально выяснили, был ли у них кто-нибудь в роду ещё с музыкальными способностями” („Знание — сила” 2003); „Очевидно, был у неё талант к э тому де лу”(С. Дов-

14 Г.А. Золотова, op. cit., s. 431. 
латов, Наши); „У Любы был талант помогать людям, в этом я убедился не только на собственном примере" (А. Рыбаков, Тяжёльй песок).

$\mathrm{W}$ analizowanych przykładach leksem talent $\mathrm{w}$ języku polskim łączy się z przydawkami przymiotnymi nietuzinkowy, przyrodzony, nieposkromiony oraz kwalitatywem w dopełniaczu bez przyimka (,talent kontaktu”), w dopełniaczu z przyimkiem do (,talent do robienia show"), w celowniku z przyimkiem po (,talent po Jaśku"). W ostatnim przykładzie rzeczownik talent ma postać liczby mnogiej i jest określony przez przymiotnik ukryty (,,ktoś ma ukryte talenty”). Z kolei w języku rosyjskim rzeczownik таланm łączy się z przydawką przymiotną необычайный oraz przydawką rzeczowną wyrażoną w celowniku z przyimkiem к („талант к этому делу”) oraz bezokolicznikiem („талант помогать”).

Oprócz rosyjskiej konstrukcji у кого-то талант к чему-то odpowiednikiem polskiej konstrukcji ktoś ma talent do czegoś jest połączenie czasownikowe uмemь талант в чём-то: „Азеры - так называли азербайджанцев - имеют особый талант в овощном деле, в выращивании и в продаже" (В. Токарева, Своя правда); „Но в шахматах имеет какой-то странный талант” (В. Аксёнов, Пора, мой друг, пора).

Zwrot иметь талант w połączeniu z przyimkiem в i formą miejscownika oznacza talent $\mathrm{i}$ jednocześnie odnoszenie sukcesów w danej dziedzinie (,успевать в овощном деле", „успевать в шахматах").

Do charakterystyki osoby utalentowanej wykorzystane zostają również zdania z czasownikami posiadać/обладать: „O Annie Marii sądzili profesorowie konserwatorium, że posiada talent całkiem nieprzeciętny" (B. Czeszko, Pokolenie); „Вот она обладает талантом живописца” (Ф. Сологуб, Королева Ортруда).

Polskie konstrukcje z czasownikami mieć, posiadać (talent) i ich rosyjskie odpowiedniki z czasownikami иметь, обладать, zdaniem G. Zołotowej, należą do nieizosemicznych modeli składniowych, które są charakterystyczne dla stylu książkowego. Trudno jest jednak uznać za modele nieizosemiczne wszystkie konstrukcje, w których leksem talent/mаланm łączy się z czasownikiem. Zarówno w języku polskim, jak i rosyjskim istnieje grupa czasowników, które informują głównie o zaistnieniu i możliwości dostrzeżenia czyjegoś talentu przez obserwatora: „Już pierwsze szkolne przedstawienie ujawnilo jego ogromny wrodzony talent sceniczny. Teatr stał się pasją jego życia” („Cosmopolitan” 1999, nr 4); „ten jednak dość szybko objawil talent rapera” (G. Brzozowicz, F. Łobodziński, 100 płyt, które wstrzasnęty światem. Kronika czasów popkultury); „Wysoka, smukła, ładna pani, również aktorka, choć talentem się nie odznaczała" (J. Przybora, Przymknięte oko opaczności); „Słynął ksiądz Bończa szeroko z krasomówczego talentu” (L. Kruczkowski, Kordian i cham); „Где он проявил блестящий талант журналиста” (РИА „Новости” 13.09.2004); „и здесь - в который раз! - обнаруживал подлинный талант беллетриста" (К. Чуковский, Репин - писатель); „Добрынин отличался талантом генерирования новых идей” (http://www.vz.ru/news/2010/4/8/391288, dostęp: 20.04.2016); 
„В особенности славился талантом импровизатора” (http://www.music-dir. ru, dostęp: 20.04.2016).

Rzeczownik talent łączy się z czasownikami przechodnimi ujawnić, objawić (talent) oraz nieprzechodnimi odznaczać się (talentem), stynąć (z talentu). $\mathrm{W}$ języku rosyjskim odpowiednikami są połączenia z czasownikami przechodnimi проявить, обнаружить (талант) oraz z czasownikami nieprzechodnimi отличаться, славиться (талантом).

$\mathrm{W}$ połączeniu z poszczególnymi przyimkami leksemy talent/maланm pełnią w zdaniu funkcję różnych okoliczników. Polskim okolicznikom przyczyny $z$ powodu talentu, dzięki talentowi $\mathrm{w}$ języku rosyjskim odpowiadają okoliczniki w postaci wyrażenia przyimkowego из-за таланта, благодаря таланту: „Przed wojną w łódzkim gimnazjum koledzy przezywali go Tarzanem, bo znakomicie chodził po drzewach, Chopinem, ale nie z powodu talentu muzycznego, lecz dlatego, że miał bujną czuprynę, i Einsteinem z powodu nieprzeciętnych zdolności matematycznych” („Gazeta Wyborcza” 28.06.1998); „Одни не хотят вставать на учет из-за гордости, другие - из-за лени, третьи - изза таланта” („Комсомольская правда” 4.06.2003); „Nash wybija się szybko dzięki talentowi i uporowi, robi karierę akademicką” („Polityka” 2.03.2002); „Ряду российских производств удалось выжить исключительно благодаря таланту их руководителей” („Воздушно-космическая оборона” 15.02.2003).

Okoliczniki przyzwolenia z przyimkami mimo/несмотря на znajdują zastosowanie w zdaniach, w których podkreślone zostaje, że talent nie gwarantuje odniesienia sukcesu w danej dziedzinie: „Właściwie m i mo ta le n $\mathrm{t} u$ i pieniędzy, choć dostał się do niej, to nigdy nie utrzymał długo” („Polityka” 9.08.2003); „Как литературные работники они, несмотря на талант, несмотря на привязанность и восторги публики, оказались бессильны в борьбе с издательским капризом и мошной” (Е. Соловьев-Андреевич, Дмитрий Писарев. Его жизнь и литературная деятельность).

Polski okolicznik sposobu w postaci wyrażenia przyimkowego $z$ talentem posiada w języku rosyjskim odpowiednik wyrażony przysłówkiem талантливo: „Nałkowska umie podpatrzeć życie i obserwacje swoje z talentem przelać na papier" („Gazeta Wyborcza” 31.07.1993); „Если музыкант играет плохо, но талантливо, готовы ли вы простить ему попадание мимо нот и приземление мимо струн?" („Вечерняя Москва” 10.01.2002); „Фильм действительно талантливо отражает то мерзкое время" (К. Чернышев, Земляным червяком).

$\mathrm{W}$ ostatnim przykładzie rosyjskim, podobnie jak w przypadku przymiotnika талантливыци, mamy do czynienia z metonimią „dzieło za twórcę”, gdyż przysłówek талантливо wraz z orzeczeniem отражает odnosi się do rzeczownika nieżywotnego фильм.

W niniejszej pracy staraliśmy się opisać izosemiczne, czyli podstawowe modele zdaniowe, wyrażające zdolności i talent $\mathrm{w}$ języku polskim i rosyjskim. Ze 
względu na ograniczenia wydawnicze nie zostały w niej rozpatrzone modele nieizosemiczne, zawierające połączenia frazeologiczne i metaforyczne.

Przeprowadzona analiza świadczy o tym, że językowy obraz zdolności i talentu jako struktura pojęciowa, utrwalona w systemie języka polskiego i rosyjskiego, a więc jego właściwościach gramatycznych i leksykalnych ${ }^{15}$, jest częściowo uniwersalny i częściowo charakterystyczny dla jednego języka. Istotne różnice związane są z użyciem krótkich form przymiotników способный, талантливый w języku rosyjskim, które nie występują w języku polskim, oraz użyciem leksemów zdolności/cnособности, talent/mалант $\mathrm{w}$ różnych formach gramatycznych w zależności od pełnionej funkcji syntaktycznej.

\section{Bibliografia}

\section{Literatura}

Grzegorczykowa R., Pojęcie językowego obrazu świata, [w:] Językowy obraz świata, red. J. Bartmiński, Wydawnictwo UMCS, Lublin 1990.

Pieter J., Stownik psychologiczny, JMP Ltd, Katowice 2004.

Reber A., Reber E., Stownik psychologii, red. I. Kurcz, K. Skarżyńska, Wydawnictwo Naukowe Scholar, Warszawa 2005.

Słownik współczesnego języka polskiego, red. B. Dunaj, Wydawnictwo Wilga, Warszawa 1996.

Włodarski Z., Matczak A., Wprowadzenie do psychologii, Wydawnictwa Szkolne i Pedagogiczne, Warszawa 1987.

Золотова Г.А., Коммуникативные аспекты русского синтаксиса, Эдиториал УРСС, Москва 2001.

Ожегов С.Н., Словарь русского языка, red. Н.Ю. Шведова, Русский язык, Москва 1990.

\section{Źródła internetowe}

http://sjp.pwn.pl/korpus

http://www.nkjp.uni.lodz.pl

http://www.ruscorpora.ru/

${ }^{15}$ R. Grzegorczykowa, Pojęcie językowego obrazu świata, [w:] Językowy obraz świata, red. J. Bartmiński, Lublin 1990, s. 43. 


\section{Sentences expressing abilities and talent in Polish and Russian languages}

Summary

The article is focused on the structural-semantic characteristics of sentences expressing abilities and talent in Polish and Russian languages. Basing on the theory of G. Zolotova the author aims to differentiate between iso-semic and non iso-semic syntactic models.

The examples for the analysis were taken from Polish and Russian languages corpora and from internet websites.

Keywords: sentence model, abilities, talent, syntactem

\section{Предложения, выражающие способности и талант в польском и русском языках}

Резюме

Настоящая статья посвящена сруктурно-семантической характеристике предложений, выражающих способности и талант в польском и русском языках. Автор пытается выделить изосемические и неизосемическине синтаксические модели, опираясь на лингвистическую теорию Г. Золотовой.

Примеры для анализа взяты из национальных корпусов польского и русского языков и веб-сайтов.

Ключевые слова: модель предложения, способности, талант, синтаксема 